Check for updates

Cite this: RSC Adv., 2018, 8, 10185

\title{
Synthesis of gemini basic ionic liquids and their application in anion exchange membranes
}

\author{
Dan Wang, Yifu Wang, Heting Wan, Jilin Wang (D) and Lulu Wang
}

A gemini-type basic morpholine ionic liquid ([Nbmd][OH]) was synthesized via a two-step method with morpholine, bromododecane and 1,4-dibromobutane as raw materials, and its structure was characterized by ${ }^{1} \mathrm{H}$ NMR and FT-IR spectroscopy. Meanwhile, a series of anion exchange membranes ([Nbmd] $\left.[\mathrm{OH}]_{x}-\mathrm{QCS}\right)$ were prepared with quaternized chitosan (QCS) as the polymer matrix and [Nbmd] $[\mathrm{OH}]$ as the dopant owing to its strong alkalinity and good solubility. The structures of the $[\mathrm{Nbmd}][\mathrm{OH}]_{x}-$ QCS composite membranes were characterized in detail by FT-IR spectroscopy, the $\mathrm{OH}^{-}$conductivity by AC impedance spectroscopy, and the morphological features by scanning electron microscopy (SEM), thermal gravity analysis (TGA), etc. The results show that the $[\mathrm{Nbmd}][\mathrm{OH}]_{x}-\mathrm{QCS}$ composite membranes have uniform surfaces and cross-section morphology. Increasing the content of [Nbmd] [OH] not only enhances the thermal stability but also increases the $\mathrm{OH}^{-}$conductivity; the thermal decomposition temperature of the $[\mathrm{Nbmd}][\mathrm{OH}]_{40}-\mathrm{QCS}$ membrane is nearly $20{ }^{\circ} \mathrm{C}$ higher than that of the pristine QCS membrane, and the maximum $\mathrm{OH}^{-}$conductivity is approximately $1.37 \times 10^{-2} \mathrm{~S} \mathrm{~cm}^{-2}$ at $70{ }^{\circ} \mathrm{C}$. The methanol permeability of the $[\mathrm{Nbmd}][\mathrm{OH}]_{40}-\mathrm{QCS}$ membrane in $1 \mathrm{M}$ methanol at room temperature is $2.21 \times 10^{-6} \mathrm{~cm}^{-2} \mathrm{~s}^{-1}$, which is lower than that of Nafion ${ }^{\circledR} 115$, indicating a promising potential use in alkaline direct methanol fuel cells. Moreover, the $[\mathrm{Nbmd}][\mathrm{OH}]_{40}-\mathrm{QCS}$ membrane exhibits the best alkaline stability of all the membranes prepared in this work, retaining approximately $81 \%$ of its initial conductivity after immersion in $3 \mathrm{M} \mathrm{KOH}$ solution for $120 \mathrm{~h}$ at $70{ }^{\circ} \mathrm{C}$.

Received 20th January 2018 Accepted 8th March 2018

DOI: $10.1039 / \mathrm{c} 8 \mathrm{ra00594j}$

rsc.li/rsc-advances

\section{Introduction}

Polymer electrolyte membrane fuel cells are generally regarded as effective energy alternatives due to their providing more power for less fuel than current thermal engines., ${ }^{1,2}$ Among them, the direct methanol fuel cell (DMFC) holds favor as a highly promising candidate for application as a portable power source on account of its ease of storage and use of methanol as a liquid fuel. As one of the most important components of fuel cells, proton exchange membranes (PEMs), such as Nafion ${ }^{\circledR}$ series membranes, have been well developed during recent decades. Although Nafion membranes exhibit high $\mathrm{OH}^{-}$conductivity and excellent thermal and chemical stability, the commercialization of proton exchange membrane fuel cells (PEMFCs) is hindered by the use of high-cost precious metal electro-catalysts, slow oxygen reduction kinetics in acidic conditions ${ }^{3,4}$ and decreased proton conductivity at temperatures above $70{ }^{\circ} \mathrm{C}$, which results in the evaporation of water from the membranes and thus limits proton mobility. ${ }^{5}$ Recently, anion exchange membrane fuel cells (AEMFCs) have exhibited many competitive advantages, such as improved

School of Petroleum and Chemical Technology, College of Chemistry, Chemical Engineering and Environmental Engineering, Liaoning Shihua University, Fushun 113001, China. E-mail: wangjilin1978@163.com electrode reaction kinetics, allowing the use of non-precious metal electro-catalysts (such as $\mathrm{Fe}, \mathrm{Co}$, and $\mathrm{Ni}$ ), reduced corrosion problems, etc., which make these fuel cells more cost effective.

At present, the studies on anion exchange membranes (AEMs) are mainly focused on chemical grafting by quaternary ammonium groups and polymer matrix modified by cationic active sites and other methods of chemical modification..$^{6-8}$ However, the primary limitations of the use of anion exchange membranes (AEMs) in AEMFCs are still the low $\mathrm{OH}^{-}$conductivity and poor chemical stability at high $\mathrm{pH}^{9,10}$ due to the degradation of cationic groups caused by direct nucleophilic substitution and/or Hofmann elimination. ${ }^{11}$

In recent years, ionic liquids (ILs), which possess unique properties including high thermal stability, high $\mathrm{OH}^{-}$conductivity and wide electrochemical windows, have been used in a large variety of applications in many kinds of chemical industries, and some achievements have been made in the application of polymer electrolyte membranes. ${ }^{12-14}$ Zhu et al. ${ }^{15}$ found that the electrochemical performance of the prepared $\mathrm{PVA} /[\mathrm{Bmim}] \mathrm{OH}$ composite membrane was significantly enhanced by the addition of ILs ([Bmim] OH), and the maximum $\mathrm{OH}^{-}$conductivity reached $1.96 \times 10^{-2} \mathrm{~S} \mathrm{~cm}^{-2}$ at ambient temperature when the mass ratio of [Bmim] $\mathrm{OH}$ to PVA was 2.0; Yi et al. ${ }^{16}$ added the imidazole ionic liquids to sulfonated 
polyetheretherketone (PEEK) and found that the thermal stability of the composite membrane containing ionic liquids was higher than that of the neat PEEK membrane, the conductivity of the composite membrane increased with the increasing content of ILs and the maximum conductivity reached $8.3 \times 10^{-2} \mathrm{~S} \mathrm{~cm}^{-2}$ at $70{ }^{\circ} \mathrm{C}$. Although some progress in the field of fuel cell exchange membranes had been made, most studies are still dominated by single-core ionic liquids. Geminitype ionic liquids, due to their dual-core structure, have somewhat stronger and more intensive basic positions (cationic active sites) than single-core ionic liquids. Thus, they exhibit higher stability and stronger alkalinity. ${ }^{17-19}$ However, unfortunately, few studies have been reported.

In this work, low-cost morpholine was used as a raw material to synthesize gemini basic morpholine ionic liquids ([Nbmd] [OH]) via a two-step procedure based on our previous work, ${ }^{20}$ and a chitosan derivative, quaternized chitosan (QCS), was used as the membrane matrix. The synthesized ionic liquids ([Nbmd] $[\mathrm{OH}])$ were locked in the structure of the membrane as dopants by the crosslinking action of glutaraldehyde (GA). Then, we prepared the composite membranes and assessed their characteristics to investigate the application potential in anion exchange membranes.

\section{Experimental}

\subsection{Materials}

Analytical grade $N$-methyl morpholine, 1-bromododecane, 1,4dibromobutane and chitosan (deacetylation degree $\geq 90.0 \%$, determined by titration ${ }^{21}$ ) were obtained from Sinopharm Chemical Reagent Co., Ltd, China. Analytical grade anhydrous ethanol, sodium hydroxide $(\mathrm{NaOH})$, potassium hydroxide $(\mathrm{KOH})$, glutaraldehyde (GA, $50 \mathrm{wt} \%$ ), glacial acetic acid, isopropanol, and hydrochloric acid were purchased from shenyang Xinhua Reagent Factory, China. (2.3-Epoxypropyl) trimethylammonium chloride (EPTMAC, purity $\geq 95 \%$ ) was commercially supplied by Shandong GuoFeng Fine Chemistry Factory.

\subsection{Methods}

2.2.1 Synthesis of dual-core basic ionic liquids (ILs). The gemini basic ILs were prepared in two steps. (1) Given amounts of 1-bromododecane and $\mathrm{NaOH}$ were added to a dry round-bottomed flask equipped with a condenser and heated to $40{ }^{\circ} \mathrm{C}$. In addition, then, $70{ }^{\circ} \mathrm{C}$ preheated $N$-methyl morpholine aqueous solution was added dropwise into the flask, and stirring was continued for $7 \mathrm{~h}$ at $130{ }^{\circ} \mathrm{C}$. After this reaction time, the mixture was allowed to rest at room temperature, and then, the upper layer was separated with a separatory funnel as the intermediate product dodecyl morpholine (molar ratio: $n_{1 \text {-bromododecane }}: n_{N \text {-methyl morpholine }}: n_{\mathrm{NaOH}^{-}}$ $: n_{\text {water }}=1: 1.2: 1.5: 5$ ). (2) A given amount of dodecyl morpholine obtained from step (1) was placed in a dry round-bottomed flask, and then 1,4-dibromobutane was added under magnetic stirring for $7 \mathrm{~h}$ at $110{ }^{\circ} \mathrm{C}$. The resulting yellow sticky liquid was dried at $50{ }^{\circ} \mathrm{C}$ under high vacuum for $24 \mathrm{~h}$. After drying, an amount of the remaining powder (bromododecyl morpholine) and $\mathrm{KOH}$ were placed in an Erlenmeyer flask at a molar ratio of $1: 2\left(n_{\text {bromododecyl }}\right.$ morpholine $: n_{\mathrm{KOH}}$ ), and then $30 \mathrm{~mL}$ of anhydrous ethanol was added until the powder was completely dissolved, and the mixture was stirred for $48 \mathrm{~h}$ at room temperature to allow adequate ion exchange to proceed. After that time, $\mathrm{KBr}$ as a white solid was separated with a centrifugal separator from the liquid mixture, the solvent ethanol was removed from the remaining liquid by vacuum distillation, and then the resulting liquid was further dried at $80{ }^{\circ} \mathrm{C}$ under high vacuum for $48 \mathrm{~h}$ to obtained the synthesized dual-core basic ionic liquids, which were termed $[\mathrm{Nbmd}][\mathrm{OH}]$. The preparation of gemini basic ILs is schematically illustrated in Scheme 1.

2.2.2 Preparation of [Nbmd][OH]-QCS membranes. QCS with a quaternization degree of $23.5( \pm 2.5) \%$ was synthesized based on our previous work. ${ }^{22}$ In a round-bottom flask equipped with a condenser and a magnetic stirrer, given amounts of QCS and $[\mathrm{Nbmd}][\mathrm{OH}]$ were dissolved in $40 \mathrm{~mL} 2 \%(\mathrm{v} / \mathrm{v})$ acetic acid aqueous solution in a $\mathrm{N}_{2}$ atmosphere at room temperature. After complete dissolution, GA aqueous solution $(2 \%, \mathrm{v} / \mathrm{v})$ was added to the mixture at a feeding rate of $0.5 \mathrm{~mL} \mathrm{~min}{ }^{-1}$ to crosslink the QCS. The final mixture was stirred at room temperature for $4 \mathrm{~h}$ and then sonicated for another $30 \mathrm{~min}$.

The resulting mixture was poured onto a glass plate, and the solvent was then evaporated in an oven at $40{ }^{\circ} \mathrm{C}$. Before characterization, the dried membrane was soaked in $1 \mathrm{M} \mathrm{KOH}$ aqueous solution for alkalization. The alkaline doping process lasted for $24 \mathrm{~h}$. The membrane was then washed thoroughly with de-ionized water and dried at $40{ }^{\circ} \mathrm{C}$ to a constant weight. All procedures were performed in $\mathrm{N}_{2}$ atmosphere. Then, the obtained anion exchange membranes were termed [Nbmd] $[\mathrm{OH}]_{x}-\mathrm{QCS}$, where $x$ denoted the final mass fraction of [Nbmd] $[\mathrm{OH}]$ in the composite membrane. The preparation of the $[\mathrm{Nbmd}][\mathrm{OH}]_{x}-\mathrm{QCS}$ membrane is schematically illustrated in Scheme 2.

\subsection{Instruments and techniques}

The nuclear magnetic resonance (NMR) spectra of [Nbmd] OH were recorded on a ${ }^{1} \mathrm{H}$ NMR spectrometer (AV ANCE III 400, Bruker Company, Germany) in $\mathrm{D}_{2} \mathrm{O}$ and calibrated with tetramethylsilane (TMS) as the internal standard. In addition, FT-IR spectroscopy (Perkin-Elmer, America) was employed to

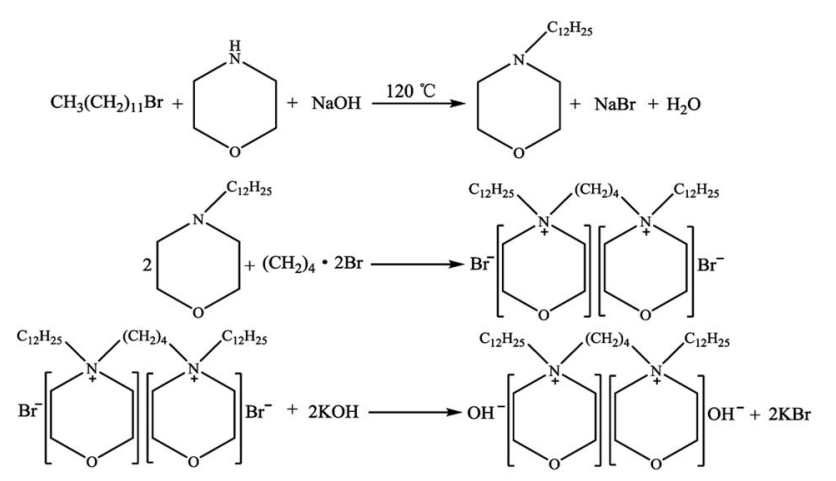

Scheme 1 Synthesis scheme of [Nbmd][OH] ILs. 


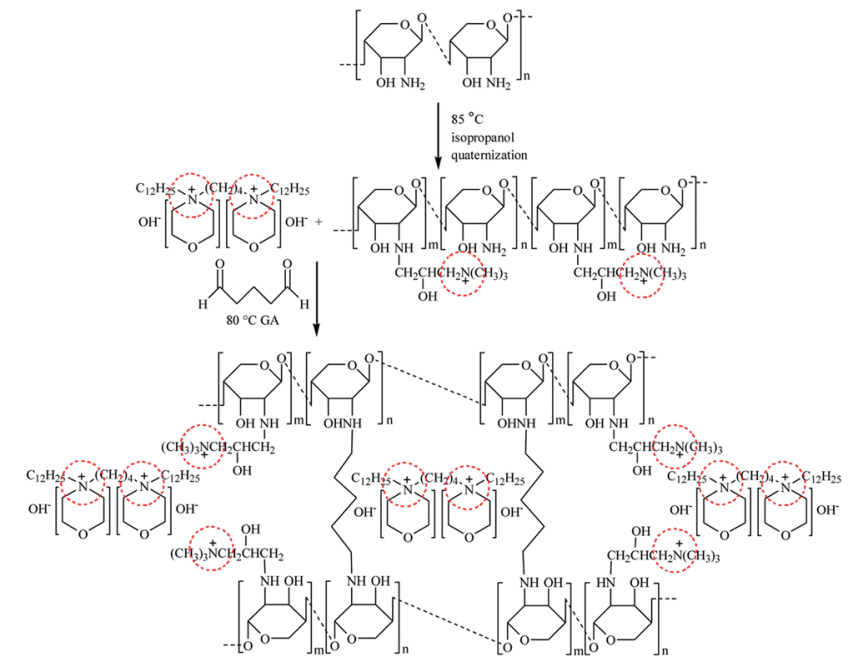

Scheme 2 Synthesis scheme of [Nbmd] [OH]-QCS membrane.

characterize the chemical composition of pure QCS and QCS/ [Nbmd] $\mathrm{OH}$ membranes, and all the samples were prepared as $\mathrm{KBr}$ pellets. The surface and cross-section of membranes were imaged using a scanning electron microscope (SEM, SSX-550, Shimadzu, Japan) after being coated with a conductive layer of sputtered gold. Thermogravimetric analysis (TGA) was performed using a TGA 290C analyzer (Netzsch Company, Germany) from 20 to $500{ }^{\circ} \mathrm{C}$ at a heating rate of $10{ }^{\circ} \mathrm{C} \mathrm{min}-1$ with continuous flushing with pure $\mathrm{N}_{2}$ at $200 \mathrm{~mL} \mathrm{~min}{ }^{-1}$. The mechanical properties of the dry membrane were determined with a CMT6502 (SANS Company, China). Dumbbell-shaped membrane samples $25 \mathrm{~mm} \times 4 \mathrm{~mm}$ in size were prepared, and the measurements were carried out by setting a constant separating speed of $5.00 \mathrm{~mm} \mathrm{~min}^{-1}$ under the ambient atmosphere. The tensile stress (TS) (MPa) was calculated by eqn (1): $:^{23}$

$$
E=F / A_{0}
$$

where $F$ is the applied force at break, $A_{0}$ is the initial crosssection area of the sample, which is equal to $4 \times L \mathrm{~mm}^{2}$, and $L$ is the thickness of the membrane.

\subsection{Water uptake (WU) and swelling ratio (SR) of the membranes}

The water uptake and swelling ratio of the composite membranes were determined by measuring the changes in the weight and dimension of the composite membranes before and after hydration. The $\mathrm{OH}^{-}$form composite membranes were immersed in de-ionized water at room temperature and equilibrated for more than $48 \mathrm{~h}$. The weight of the wet membrane was measured after wiping off the excess surface water. Then, the wet membrane was dried under vacuum at a fixed temperature of $60^{\circ} \mathrm{C}$ until a constant dry weight was obtained. The WU and SR were calculated by the following equations: ${ }^{24,25}$

$$
\begin{aligned}
& \mathrm{WU}(\%)=\left(m_{\text {wet }}-m_{\text {dry }}\right) / m_{\text {dry }} \times 100 \% \\
& \mathrm{SR}(\%)=\left(X_{\text {wet }}-X_{\text {dry }}\right) / X_{\text {dry }} \times 100 \%
\end{aligned}
$$

where $m_{\text {wet }}$ is the mass $(\mathrm{g})$ of the wet membrane; $m_{\mathrm{dry}}$ is the mass ( $g$ ) of the dry membrane; $X_{\text {wet }}$ is the dimension of the wet membrane; and $X_{\mathrm{dry}}$ is the dimension of the dry membrane.

\subsection{Ion exchange capacity (IEC)}

The IEC value is one of the important indices of the membrane conductivity performance. In this work, the IEC was measured using the conventional back titration method. A membrane sample (in $\mathrm{OH}^{-}$form) with known dry mass was first equilibrated with DI water for at least $24 \mathrm{~h}$ and rinsed copiously to remove any physisorbed ions; it was then soaked in a known volume of $0.01 \mathrm{M}$ hydrochloric acid $(\mathrm{HCl})$ for $48 \mathrm{~h}$ to change the membrane to the $\mathrm{Cl}^{-}$form. The $\mathrm{HCl}$ solution was titrated against $0.01 \mathrm{M} \mathrm{NaOH}$ (aq.) with phenolphthalein as an indicator. The IEC was calculated as follows: ${ }^{26}$

$$
\mathrm{IEC}=\left(C_{\mathrm{HCl}} V_{\mathrm{HCl}}-C_{\mathrm{NaOH}} V_{\mathrm{NaOH}}\right) / W_{\mathrm{dry}} \times 100 \%
$$

where $W_{\mathrm{dry}}$ is the mass of the dried membrane, $C_{\mathrm{HCl}}$ and $C_{\mathrm{NaOH}}$ are the concentrations of $\mathrm{HCl}$ and $\mathrm{NaOH}$ solution, respectively, and $V_{\mathrm{HCl}}$ and $V_{\mathrm{NaOH}}$ are the volumes of $\mathrm{HCl}$ solution and $\mathrm{NaOH}$ solution consumed in the titration, respectively.

\subsection{Anionic $\left(\mathrm{OH}^{-}\right)$conductivity}

The $\mathrm{OH}^{-}$conductivity of the membranes was measured by an electrochemical impedance analyzer (CHI760) with an alternating current (AC) frequency scanned from $100 \mathrm{kHz}$ to $0.1 \mathrm{~Hz}$ at a voltage amplitude of $100 \mathrm{mV}$. The fully hydrated membrane was sandwiched in a Teflon electrolyte cell equipped with Pt strips. ${ }^{27}$ The impedance was measured by placing the cell in a temperature-controlled chamber at a temperature range from $20{ }^{\circ} \mathrm{C}$ to $90{ }^{\circ} \mathrm{C}$. The $\mathrm{OH}^{-}$conductivity $(\sigma)$ of the membrane was calculated by eqn (5):

$$
\sigma\left(\mathrm{S} \mathrm{cm}^{-1}\right)=1 / R_{\mathrm{m}} \times S
$$

where $l$ is the thickness of the membrane $(\mathrm{cm}), S$ is the membrane surface area $\left(\mathrm{cm}^{-2}\right)$ for ion transport, and $R_{\mathrm{m}}$ is the membrane resistance $(\Omega)$ from the AC impedance data. The temperature was controlled by placing the conductivity measurement cell in an oven. The thicknesses of the membranes were obtained by previous swelling of the samples in the electrolyte solution before the measurements to prevent any deviation resulting from distortion of the membranes. All operations were performed in $\mathrm{N}_{2}$ atmosphere to prevent $\mathrm{OH}^{-}$ from changing to $\mathrm{HCO}_{3}{ }^{-}$(or $\mathrm{CO}_{3}{ }^{2-}$ ) by reacting with $\mathrm{CO}_{2}$.

\subsection{Methanol permeability}

The methanol permeability of the composite membranes was determined at room temperature using a homemade diffusion cell consisting of two compartments. To ensure uniformity during the experiments, magnetic stirrers were used in each compartment. The membrane was clamped between the two compartments. One compartment was loaded with $1 \mathrm{M}$ methanol aqueous solution (compartment A) and the other with deionized water (compartment B). The methanol concentration 
resulting from permeation in compartment (B) at any time $t$ (in seconds), i.e., $C_{\mathrm{B}}$ in $\mathrm{mmol} \mathrm{L}^{-1}$, was monitored using a gas chromatograph (GC-6820, Agilent, USA). The methanol permeability $P\left(\mathrm{~cm}^{-2} \mathrm{~s}^{-1}\right)$ through the membrane was calculated by eqn (6):

$$
P=L C_{\mathrm{B}} V_{\mathrm{B}} /\left(A^{2}\left(C_{\mathrm{A}}-C_{\mathrm{B}}\right) t\right)
$$

where $A\left(\mathrm{~cm}^{2}\right)$ and $L(\mathrm{~cm})$ are the membrane area and thickness, respectively; $C_{\mathrm{A}}\left(\mathrm{mmol} \mathrm{\textrm {L } ^ { - 1 }}\right)$ is the initial concentration of methanol in compartment $(\mathrm{A})$; and $V_{\mathrm{B}}(\mathrm{mL})$ is the water volume in compartment (B).

\subsection{Alkaline resistance stability}

The alkaline resistance stability was investigated by monitoring the conductivity of the membranes as a function of immersion time in $\mathrm{KOH}$ solutions. The detailed procedure was that the membranes were immersed in aqueous $\mathrm{KOH}(3 \mathrm{M})$ solutions at room temperature for different times. They were later thoroughly washed with de-ionized water (to remove the excess $\mathrm{KOH})$ and immersed in de-ionized water for more than $24 \mathrm{~h}$ prior to the measurement of ionic conductivity at $70{ }^{\circ} \mathrm{C}$. To distinguish the $\mathrm{OH}^{-}$conductivity of the membrane treated in $\mathrm{KOH}$ solution for $0 \mathrm{~h}$ and the composite membrane treated for different times (immersion time $>0 \mathrm{~h}$ ), the former was designated $\sigma_{0}$, and the latter was designated $\sigma_{\mathrm{t}}$. The $\sigma_{\mathrm{t}} / \sigma_{0}$ ratios were recorded as a function of immersion time in the $\mathrm{KOH}$ solution.

\subsection{Membrane electrode assemblies and fuel cell tests}

Commercial Pt-Ru/C (30 wt\% Pt, $15 \mathrm{wt} \% \mathrm{Ru}$ ) for the anode and $\mathrm{Pt} / \mathrm{C}(20 \mathrm{wt} \% \mathrm{Pt}$ ) for the cathode were purchased from Johnson Matthey. The loading of Pt-Ru and Pt catalysts at the anode and cathode were both $0.5 \mathrm{mg} \mathrm{cm}^{-2}$. The obtained membrane/ electrodes assembly (MEA) was then set into a $5 \mathrm{~cm}^{2}$ fuel cell for testing using a commercial fuel cell system (Arbin Instrument Corporation). $5 \mathrm{M} \mathrm{KOH}$ and $3 \mathrm{M}$ ethanol were fed to the anode at a flow rate of $1 \mathrm{~mL} \mathrm{~min}^{-1}$ to provide three-phase boundary and sufficient $\mathrm{OH}^{-}$. At the same time, the cathode was supplied with $0.2 \mathrm{MPa} \mathrm{O}_{2}$.

\section{Results and discussion}

\subsection{Characterization of [Nbmd $][\mathrm{OH}]$ by ${ }^{1} \mathrm{H}$ NMR and FT-IR}

Fig. 1 shows the ${ }^{1} \mathrm{H}$ NMR spectra of the synthesized [Nbmd][OH] (400 MHz, $\mathrm{D}_{2} \mathrm{O}$, TMS; ppm): $a=0.89\left(6 \mathrm{H},-\mathrm{CH}_{3}\right), b=1.27(32 \mathrm{H}$, $\left.-\left(\mathrm{CH}_{2}\right)_{8}{ }^{-}\right), c=1.33\left(4 \mathrm{H},-\mathrm{CH}_{2}-\right), d=1.75\left(4 \mathrm{H},-\mathrm{CH}_{2}-\right), g=1.81$ $\left(4 \mathrm{H},-\mathrm{CH}_{2}-\right), h=3.29\left(8 \mathrm{H},-\mathrm{CH}_{2}-\right), e=3.45\left(4 \mathrm{H},-\mathrm{CH}_{2}-\right), f=3.57$ $\left(4 \mathrm{H},-\mathrm{CH}_{2}-\right), i=3.88\left(8 \mathrm{H},-\mathrm{CH}_{2}-\right)$, which are consistent with the hydrogen proton positions and numbers. The peak belonging to the $\mathrm{OH}^{-}$was absent from the spectrum of $[\mathrm{Nbmd}][\mathrm{OH}]$, probably due to substitution by deuterium from $\mathrm{D}_{2} \mathrm{O}$.

FT-IR was employed to study the chemical structure of the synthesized [Nbmd][OH] (Fig. 2), where the band at $3439 \mathrm{~cm}^{-1}$ is assigned to the stretching vibration of $\mathrm{O}-\mathrm{H}^{28}$ caused by residual ethanol. The bands at $2925 \mathrm{~cm}^{-1}$ and $2856 \mathrm{~cm}^{-1}$ are attributed to the saturated $\mathrm{C}-\mathrm{H}$ stretching vibration. ${ }^{29}$ The bands at $1479 \mathrm{~cm}^{-1}$ results from the $-\mathrm{CH}_{2}$ deformation vibration in alkane. ${ }^{30}$ The band at approximately $725 \mathrm{~cm}^{-1}$ indicates the presence of long-chain alkanes in $[\mathrm{Nbmd}][\mathrm{OH}] .^{20}$ The stretching vibration of $\mathrm{C}-\mathrm{N}-\mathrm{C}$ can be observed at $1061 \mathrm{~cm}^{-1}$, and the band at $1115 \mathrm{~cm}^{-1}$ originates from the $\mathrm{C}-\mathrm{O}-\mathrm{C}$ skeleton stretching vibration of the morpholine ring. ${ }^{31}$ As mentioned above, the test sample has both alkyl chains and morpholine rings, which is consistent with the predicted chemical structure of the synthesized [Nbmd][OH]. The cooperative analysis of FT-

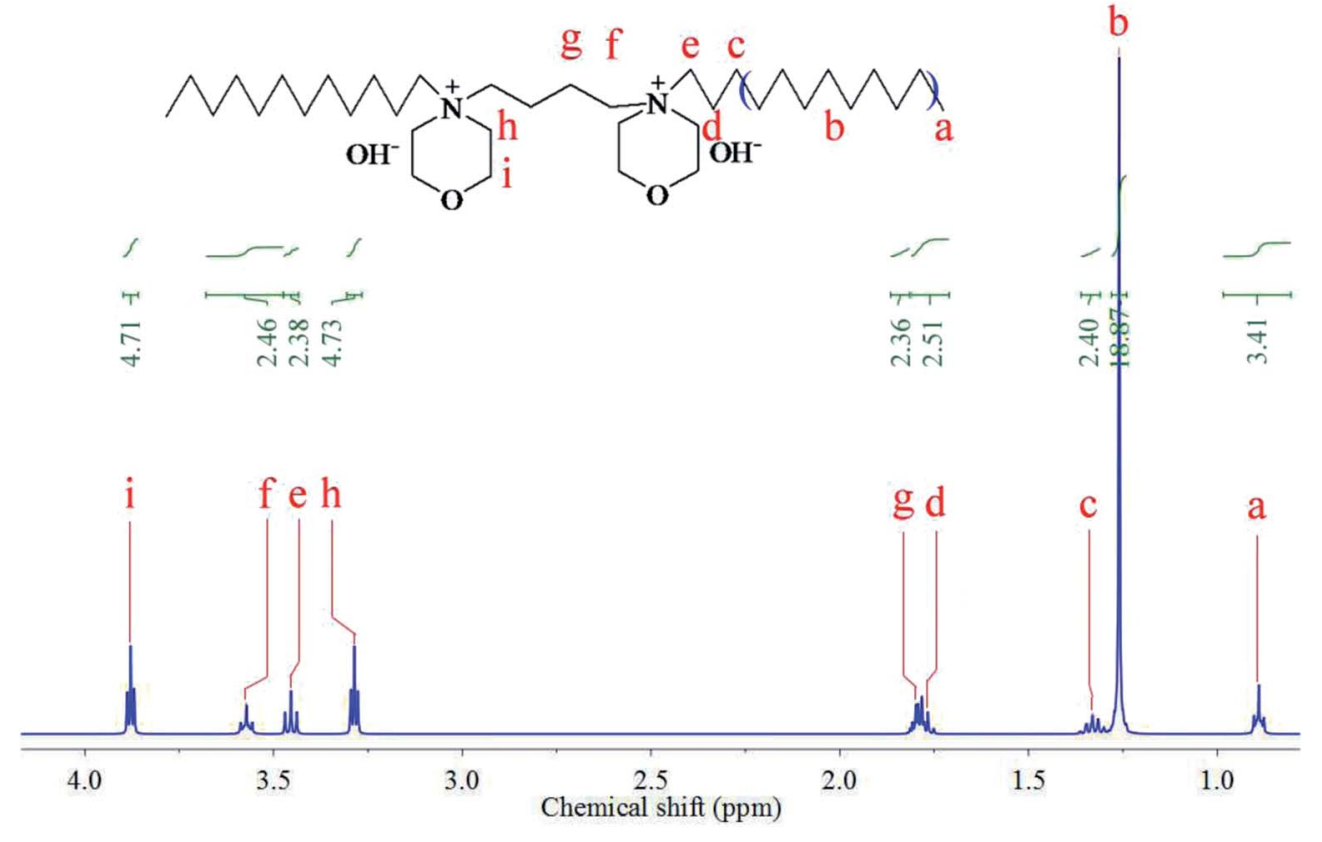

Fig. $1{ }^{1} \mathrm{H}$ NMR spectrum of the synthesized [Nbmd] [OH]. 


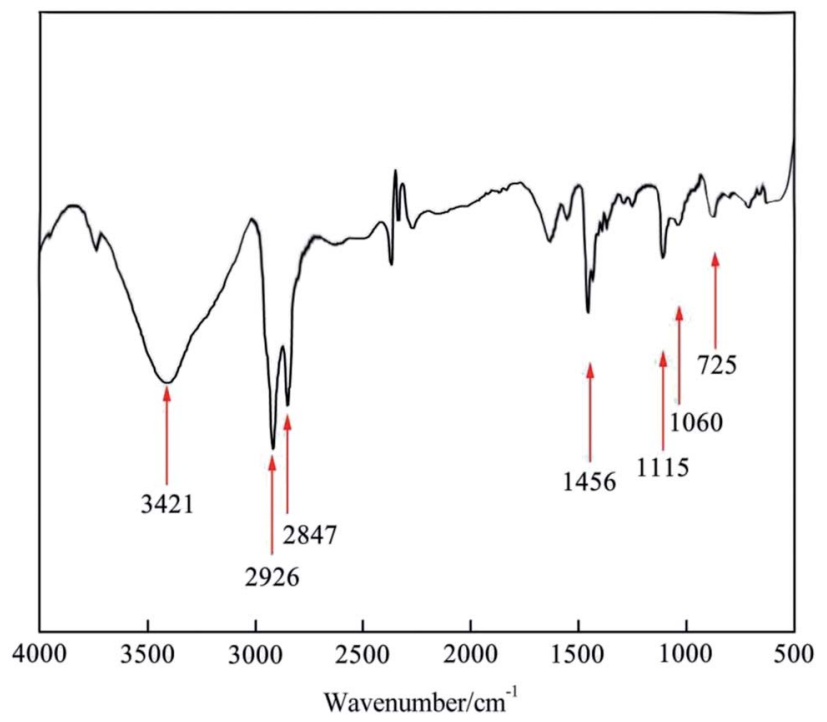

Fig. 2 FT-IR spectrum of the synthesized [Nbmd] [OH].

IR spectra and ${ }^{1} \mathrm{H}$ NMR spectra proved that the $[\mathrm{Nbmd}][\mathrm{OH}]$ was successfully synthesized.

\subsection{Alkalinity and solubility of [ $\mathrm{Nbmd}][\mathrm{OH}]$}

Different concentrations of [Nbmd] $[\mathrm{OH}]$ at $25{ }^{\circ} \mathrm{C}$. As seen in Table 1 , the $[\mathrm{Nbmd}][\mathrm{OH}]$ aqueous solution shows a weaker alkaline character than $\mathrm{KOH}$ aqueous solution at the same concentration. However, the alkaline intensity of [Nbmd][OH] aqueous solution could also meet the requirements for attracting $\mathrm{OH}^{-}$. In addition, for application in the anion exchange membranes of fuel cells, the problem of catalyst deactivation and $\mathrm{CO}_{2}$ deposition caused by the traditional alkali doping method can be avoided. Hence, the synthesized ionic liquid $[\mathrm{Nbmd}][\mathrm{OH}]$ in this work has practical significance.

Table 2 lists the solubility of the synthesized $[\mathrm{Nbmd}][\mathrm{OH}]$ in different solvents at $20^{\circ} \mathrm{C}$. As expected by the theory that similar substances can be dissolved easily in each other, the ionic liquids are soluble in strong polar solvents rather than nonpolar solvents. As shown in Table 2, the [Nbmd][OH] ionic liquids synthesized in this work have good solubility in common organic solvents, which may be due to the protonation of morpholine rings. This property is of great practical

Table $1 \mathrm{pH}$ values of different concentrations of [ $\mathrm{Nbmd}][\mathrm{OH}]$ aqueous solution and $\mathrm{KOH}$ aqueous solution at $25^{\circ} \mathrm{C}$

\begin{tabular}{lll}
\hline & $\mathrm{pH}$ value & \\
\cline { 2 - 3 } Concentration/ $\mathrm{mol} \mathrm{L}^{-1}$ & $\begin{array}{l}{[\mathrm{Nbmd}][\mathrm{OH}]} \\
\text { solution }\end{array}$ & $\begin{array}{l}\text { KOH } \\
\text { solution }\end{array}$ \\
\hline 0.1 & 10.74 & 12.9 \\
0.05 & 10.01 & 12.6 \\
0.01 & 9.1 & 11.9
\end{tabular}

Table 2 Solubility of $[\mathrm{Nbmd}][\mathrm{OH}]$ in different solvents ${ }^{a}$

\begin{tabular}{lc}
\hline Solvent & Solubility \\
\hline Water & + \\
Methanol & + \\
Ethanol & + \\
Glycerol & - \\
Dichloromethane & + \\
Ether & - \\
Ethyl acetate & - \\
$a_{+}$Soluble; -: insoluble. & \\
&
\end{tabular}

significance for the preparation of anion exchange membranes with different polymer matrices.

\subsection{Characterization of $[\mathrm{Nbmd}][\mathrm{OH}]_{x}-\mathrm{QCS}(x=10,20,30$, 40) membranes by FT-IR}

Fig. 3 presents the FT-IR spectra of CS, QCS and [Nbmd] [OH $]_{x^{-}}$ QCS $(x=10,30)$, respectively. As shown in Fig. 3, broad bands at approximately $3439 \mathrm{~cm}^{-1}$ are observed for all the membrane samples, which are assigned to the vibration of both $\mathrm{N}-\mathrm{H}$ and $\mathrm{O}-\mathrm{H}$ as a result of overlap. The band at $1594 \mathrm{~cm}^{-1}$ for CS is due to the $\mathrm{N}-\mathrm{H}$ bending vibration of the primary amino group; however, there is no distinct absorption associated with the $\mathrm{N}-\mathrm{H}$ bending vibration of the primary amine at $1594 \mathrm{~cm}^{-1}$ for QCS-0\%. Instead, a new band at approximately $1640 \mathrm{~cm}^{-1}$ was recorded for QCS-0\%, revealing the transformation of the primary amine to a secondary amine due to the quaternary reactions at $-\mathrm{NH}_{2}$ sites on the chitosan chains. ${ }^{18}$ In addition, the increased absorptions at $2925 \mathrm{~cm}^{-1}, 2856 \mathrm{~cm}^{-1}$ and $1479 \mathrm{~cm}^{-1}$ assigned to the $\mathrm{C}-\mathrm{H}$ vibration and bending of the trimethylammonium group for QCS-X membranes also indicate the

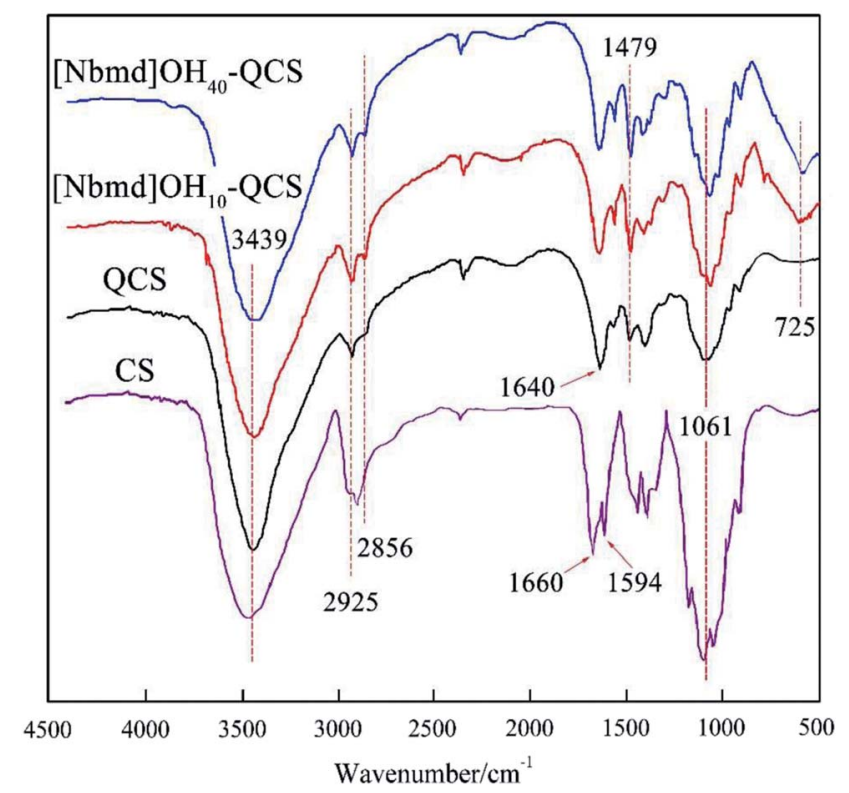

Fig. 3 FT-IR spectrum of the CS, QCS and $[\mathrm{Nbmd}][\mathrm{OH}]_{x}-\mathrm{QCS}(x=10$, 30) membranes. 
existence of quaternary ammonium groups in the QCS. ${ }^{30}$ The band at $1061 \mathrm{~cm}^{-1}$ corresponds to the $\mathrm{C}-\mathrm{O}-\mathrm{C}$ skeleton stretching vibration of the morpholine ring. In addition, a main band at $725 \mathrm{~cm}^{-1}$ attributed to a long-chain alkane can be observed in $[\mathrm{Nbmd}][\mathrm{OH}]_{x}-\mathrm{QCS}(x=10,30)$ membranes, but no band appears in QCS, which indicates the presence of [Nbmd] $[\mathrm{OH}]$ in the membranes. Moreover, during the preparation of the $[\mathrm{Nbmd}][\mathrm{OH}]_{x}-\mathrm{QCS}$ membranes, increasing the content of $[\mathrm{Nbmd}][\mathrm{OH}]$ resulted in increasingly large numbers of $-\mathrm{CH}_{2}-$ in alkyl chains, which can be confirmed by the increased intensity of the $725 \mathrm{~cm}^{-1}$ band. The same structure of $-\mathrm{CH}_{2}-$ in alkyl chains can also be proved by ${ }^{1} \mathrm{H}$ NMR, as shown in Fig. 1 (chemical shift $b$ ).

\subsection{Membrane morphologies}

SEM photographs of the surface and the cross-sectional views of the $[\mathrm{Nbmd}][\mathrm{OH}]_{x}-\mathrm{QCS}$ membranes are shown in Fig. 4. For the first two membranes (A and B), the surfaces are clearly smooth, and both cross-sectional views show complete, compact structure and no obvious holes can be observed. The structures are compact due to the lower $[\mathrm{Nbmd}][\mathrm{OH}]$ content. For the last two membranes (C and D), some dots are clearly visible on the surfaces due to the increased $[\mathrm{Nbmd}][\mathrm{OH}]$ content, and the cross-sectional views are still compact, with no phase separation phenomena. The results indicate that QCS and [Nbmd] $[\mathrm{OH}]$ are combined well with GA as the crosslinking reagent.

\subsection{Mechanical properties of the $[\mathrm{Nbmd}][\mathrm{OH}]_{x}-\mathrm{QCS}$ membranes}

Stress-strain tests were used to determine the mechanical properties of the $[\mathrm{Nbmd}][\mathrm{OH}]_{x}-\mathrm{QCS}$ membranes $(x=10,20,30$, 40) with various concentrations of $[\mathrm{Nbmd}][\mathrm{OH}]$, as well as
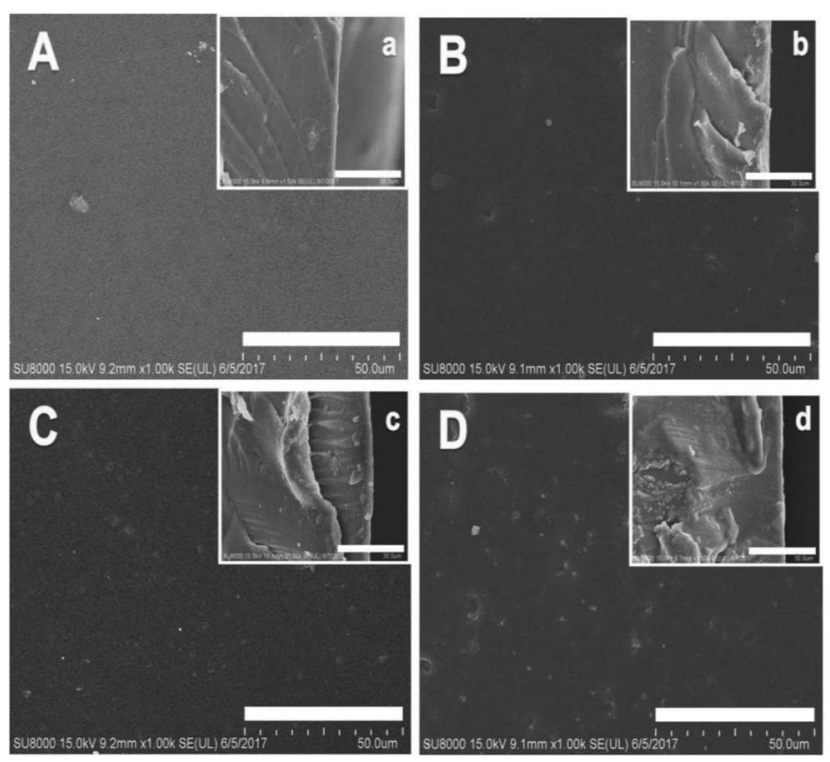

Fig. 4 Surface (A, B, C and D) and cross-sectional ( $a, b, c$ and d) SEM images of $[\mathrm{Nbmd}][\mathrm{OH}]_{x}-$ QCS membranes $(x=10,20,30,40$, respectively). commercial QCS, as shown in Fig. 5. The TS values are in the range of 14.39-9.12 $\mathrm{MPa}$, and the $E_{\mathrm{b}}$ values (elongation at break) are in the range of $49.1-96.2 \%$. It can be seen that the TS values tend to decrease as the $[\mathrm{Nbmd}][\mathrm{OH}]$ content increases because a higher proportion of $[\mathrm{Nbmd}][\mathrm{OH}]$ means a lower proportion of the QCS matrix, thus reducing the number of $-\mathrm{NH}_{2}$ groups available as crosslinking sites. This change would weaken the crosslinking effect, leading to a decrease in tensile strength. However, the $E_{\mathrm{b}}$ values show an increasing trend because the number of long alkyl chains increases with the increasing [Nbmd][OH] content, which improves the flexibility of the membranes. In addition, a larger number of hydrophilic quaternary ammonium groups in membrane means that more moisture is drawn into membrane, which will also lead to better flexibility of the membrane.

We listed some membranes' mechanical properties reported in recent 5 years. As shown in Table 3, the prepared membranes in our work though show somewhat less tensile strength but with excellent elongation at break and they still have the potential to be used in fuel cells. At $80{ }^{\circ} \mathrm{C}$, the tensile strength of the prepared membranes decreased slightly, which may be due to fact that the increasing temperature makes polymer chain activity more intensely, more likely to produce the intermolecular slippage or intermolecular pull phenomenon.

\subsection{TGA curves of $[\mathrm{Nbmd}][\mathrm{OH}]_{x}-\mathrm{QCS}$ membranes}

Fuel cell performance generally improves at elevated temperature, and the range of $40-120{ }^{\circ} \mathrm{C}$ is of interest. Therefore, the thermal stability of the AEM is a key metric in forming ionic conducting ionomers for use in a fuel cell. Thermogravimetric analysis was carried out on the AEMs synthesized in this work to investigate their thermal stability. The TGA curves for QCS, $[\mathrm{Nbmd}][\mathrm{OH}]_{x}-\mathrm{QCS}$ membranes $(x=10,40)$ and $[\mathrm{Nbmd}][\mathrm{OH}]$ ionic liquids are shown in Fig. 6. Clearly, the mass loss of the $[\mathrm{Nbmd}][\mathrm{OH}]$ is much less than that of the neat QCS and [Nbmd]

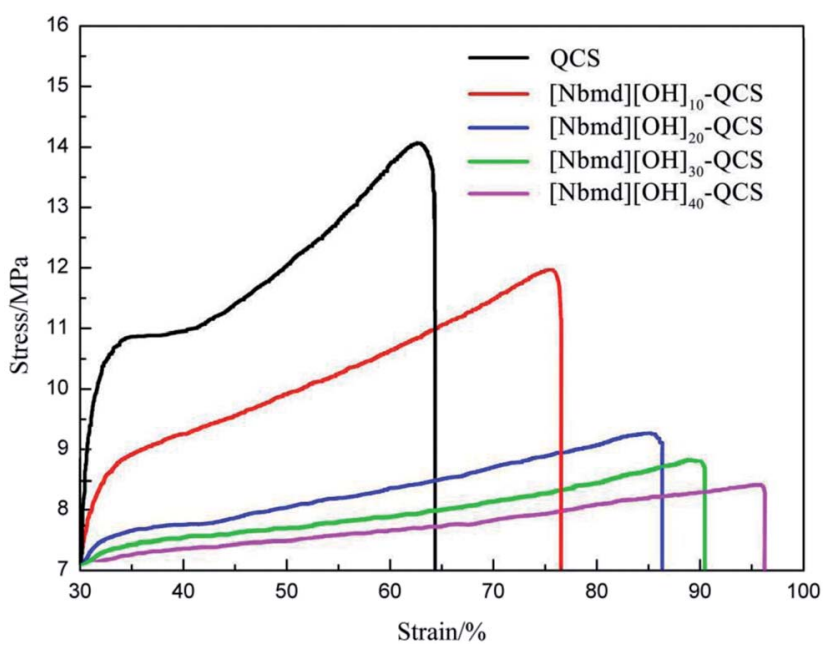

Fig. 5 Stress-strain curves of $[\mathrm{Nbmd}][\mathrm{OH}]_{x}-\mathrm{QCS}$ membranes $(x=10$, $20,30,40)$ at various concentrations of $[\mathrm{Nbmd}][\mathrm{OH}]$, as well as commercial QCS. 
Table 3 Mechanical properties of the membranes ${ }^{a}$

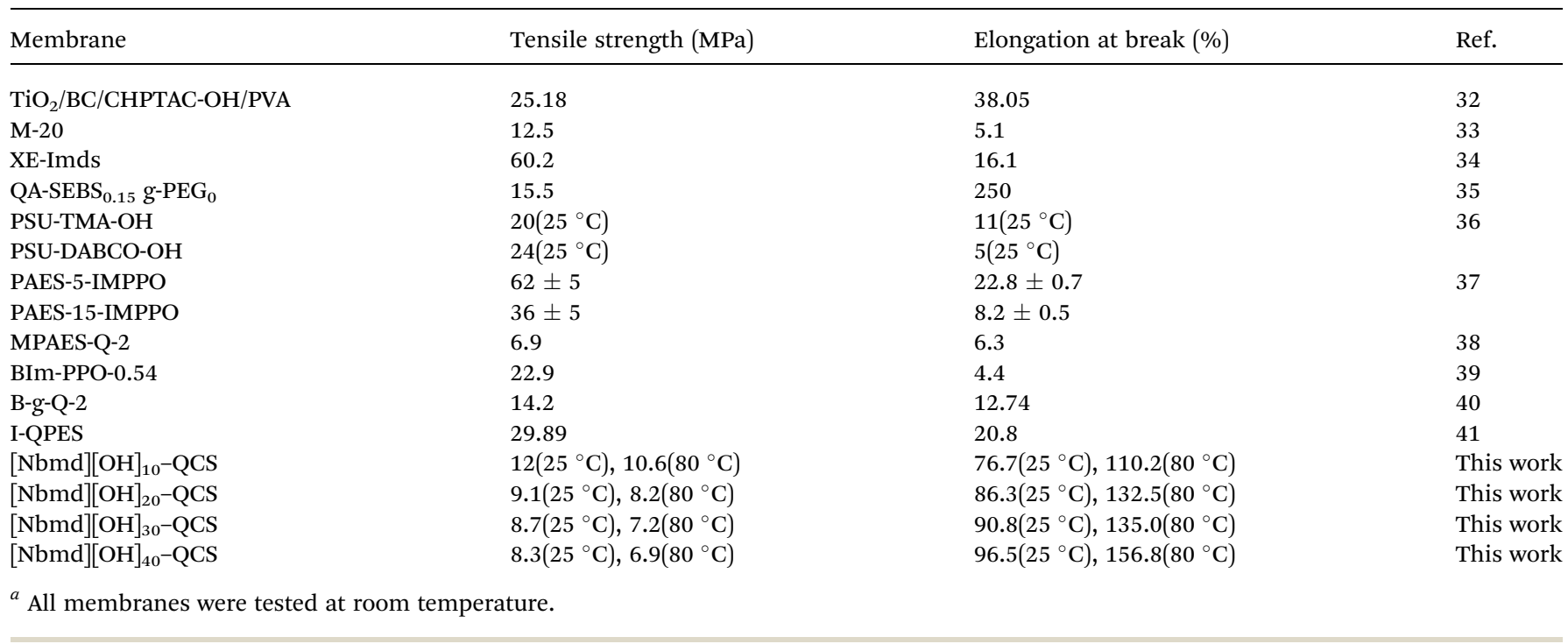

$[\mathrm{OH}]_{x}-\mathrm{QCS}$ membranes $(x=10,40)$ within the temperature range of $100-350{ }^{\circ} \mathrm{C}$. It can be seen that $[\mathrm{Nbmd}][\mathrm{OH}]$ starts degrading at approximately $300{ }^{\circ} \mathrm{C}$, which shows excellent thermal stability, corresponding to the ring structure of morpholine. $^{42}$ Neat QCS membrane and $[\mathrm{Nbmd}][\mathrm{OH}]_{x}-\mathrm{QCS}$ membranes $(x=10,40)$ all exhibit two degradation stages. The first stage $\left(50-120^{\circ} \mathrm{C}\right)$ is mainly attributed to the evaporation of moisture (mainly bonded water), and the second stage (240-300 ${ }^{\circ} \mathrm{C}$ ) is due to the decomposition of the QCS backbone (mainly quaternary ammonium groups). As seen from the enlarged illustrations, the degradation temperature of the [Nbmd] $[\mathrm{OH}]_{10}$-QCS membrane is $5{ }^{\circ} \mathrm{C}$ higher than that of the neat QCS membrane, and as the content of $[\mathrm{Nbmd}][\mathrm{OH}]$ increases from $10-40 \%$, the degradation temperature is increased by approximately $15{ }^{\circ} \mathrm{C}$, which means that the thermal stability of the $[\mathrm{Nbmd}][\mathrm{OH}]_{x}-\mathrm{QCS}$ membranes improves greatly when more [Nbmd] $[\mathrm{OH}]$ is added. As the temperature exceeds $400{ }^{\circ} \mathrm{C}$, the residual mass of all samples tends to be stable; moreover, the

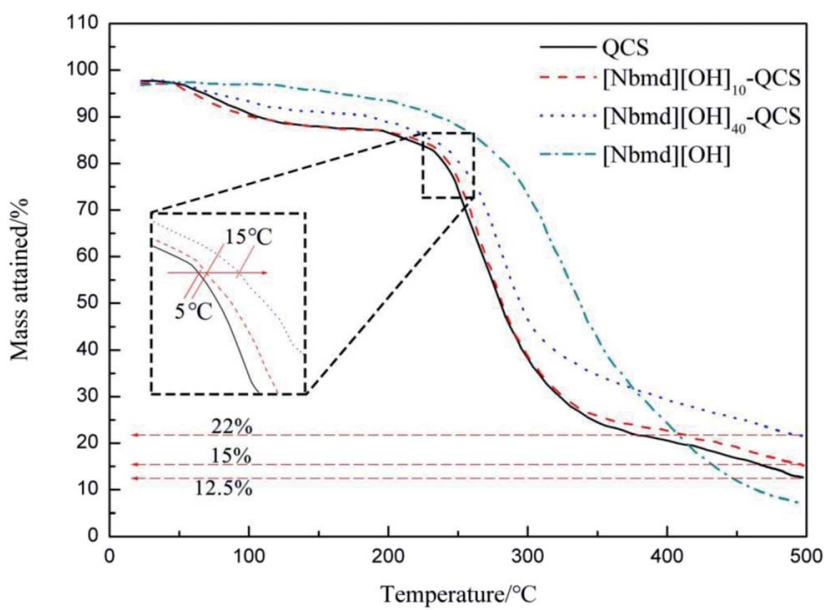

Fig. 6 TGA curves for pure QCS membrane, $[\mathrm{Nbmd}][\mathrm{OH}]_{x}-\mathrm{QCS}$ membrane $(x=10,40)$ and $[\mathrm{Nbmd}][\mathrm{OH}]$. mass of the $[\mathrm{Nbmd}][\mathrm{OH}]_{40}-\mathrm{QCS}$ membrane is $7 \%$ higher than that of the $[\mathrm{Nbmd}][\mathrm{OH}]_{10}-\mathrm{QCS}$ membrane, which is due to the increased proportion of $[\mathrm{Nbmd}][\mathrm{OH}]$.

\subsection{Dynamic swelling behavior of QCS and $[\mathrm{Nbmd}][\mathrm{OH}]_{x^{-}}$ QCS membranes}

The membrane swelling undergoes three stages, they are the diffusion of water molecules into the membrane structure and the relaxation of the polymer structure caused by the hydration and extension of macromolecule chains. ${ }^{43-45}$ All the membranes prepared in this research performed very fast water absorption, and they all reached swelling equilibrium within 10 min which can be seen in Fig. 7. This rapidity is due to the large amount of hydrophilic quaternary ammonium groups in the membrane structure. With increasing [Nbmd][OH] content, the swelling ratio of the composite membranes increases. This increase may be caused by the following two reasons: the number of quaternary ammonium groups is twice the number of $[\mathrm{Nbmd}][\mathrm{OH}]$ molecules because each $[\mathrm{Nbmd}][\mathrm{OH}]$ has two quaternary ammonium groups, which greatly increases the number of hydrophilic quaternary ammonium groups; and more [Nbmd] $[\mathrm{OH}]$ means less QCS, resulting in a decreased number of amino groups as crosslinking sites. The decrease in the degree of crosslinking makes the structure of the composite membrane loose, which increases the space for holding water molecules.

To better understand the swelling mechanism of the composite membranes in the process of water absorption, the swelling process of the composite membranes was fitted by the Schott second-order swelling kinetic equation as follows: ${ }^{46}$

$$
t / W_{\mathrm{t}}=1 /\left(K_{\mathrm{S}} W_{\infty}^{2}\right)+t / W_{\infty}
$$

where $W_{\mathrm{t}}$ is the swelling ratio of the membrane after immersion time $t ; W_{\infty}$ is the swelling ratio of the membrane after reaching swelling equilibrium; and $K_{\mathrm{S}}$ is the swelling rate constant, which is calculated from the slope $\left(1 / W_{\infty}\right)$ and intercept (1/ 


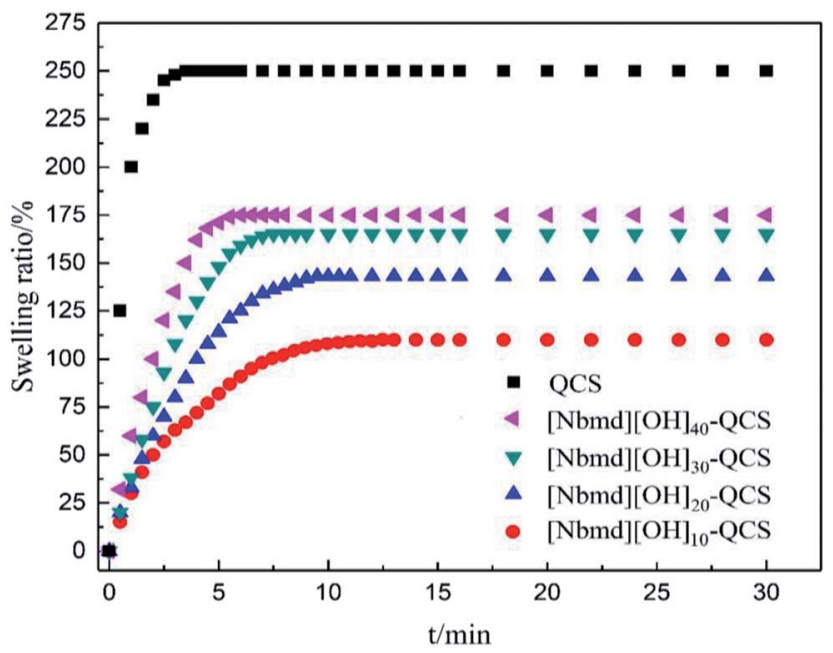

Fig. 7 Dynamic swelling behavior of QCS and $[\mathrm{Nbmd}][\mathrm{OH}]_{x}-\mathrm{QCS}$ membranes $(x=10,20,30,40)$ in de-ionized water at room temperature.

$K_{\mathrm{S}} W_{\infty}^{2}$ ) of the plots of the Schott second-order swelling kinetic equation.

The data obtained from the swelling process (see Fig. 10) were substituted into eqn (7). The reciprocal of the swelling rate $\left(t / W_{\mathrm{t}}\right)$ had a good linear relationship with the time $(t)$ of the swelling process. The swelling kinetic parameters are listed in Table 4. As seen in Table 4, the experimental equilibrium swelling ratio and the theoretical equilibrium swelling ratio are close to each other, and the determination coefficients $\left(R^{2}\right)$ are all larger than 0.995 , indicating that the swelling processes of the QCS and the series of composite membranes follow the Schott second-order swelling kinetics model. When the [Nbmd] $[\mathrm{OH}]$ content increases from $10 \%$ to $30 \%$, the swelling rate constant increases from $3.53 \times 10^{-3}$ to $5.00 \times 10^{-3}$ because more $[\mathrm{Nbmd}][\mathrm{OH}]$ means less QCS, resulting in a decrease in

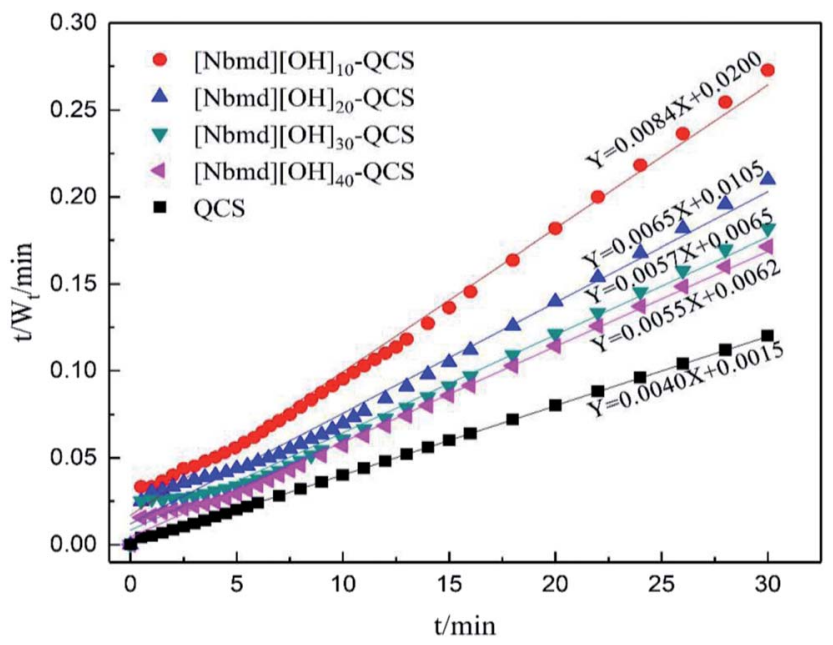

Fig. 8 Variation in the reciprocal rate of swelling $t / W t$ as a function of the swelling time for QCS and $[\mathrm{Nbmd}][\mathrm{OH}]_{x}-\mathrm{QCS}$ membranes $(x=10$, $20,30,40)$ in de-ionized water at room temperature.

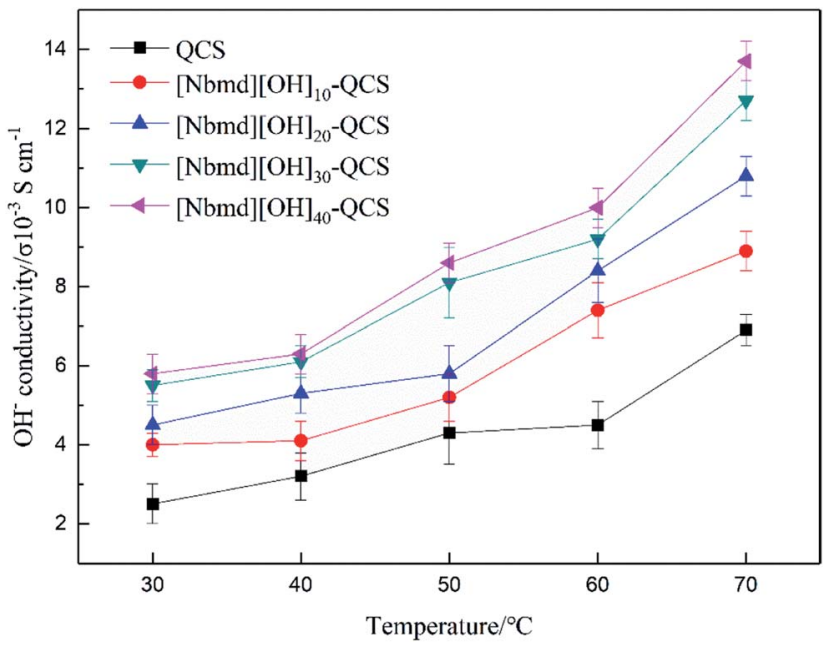

Fig. $9 \mathrm{OH}^{-}$conductivity of $\mathrm{QCS}$ and $[\mathrm{Nbmd}][\mathrm{OH}]_{x}-\mathrm{QCS}$ membranes $(x=10,20,30,40)$.

the number of crosslinking sites (e.g., $\left.-\mathrm{OH},-\mathrm{NH}_{2}\right)$. In addition, the large steric hindrance of $[\mathrm{Nbmd}][\mathrm{OH}]$ could also hinder the crosslinking effect, making the membrane structure relatively loose. These factors lead to the result that water molecules are more likely to diffuse into the relatively loose membrane structure, thus increasing the swelling rate constant. However, when the $[\mathrm{Nbmd}][\mathrm{OH}]$ content continues to increase to $40 \%$, the swelling rate constant is reduced, which may be related to the fact that a larger number of hydrophobic alkane tail chains causes excessive extrusion into the hydrophilic region, blocking the diffusion of water molecules and thus reducing the swelling rate constant. From another point of view, at a certain temperature, the composite membrane with higher [Nbmd] $[\mathrm{OH}]$ content would have a stronger ability to hold moisture, which is beneficial for improving water retention at high

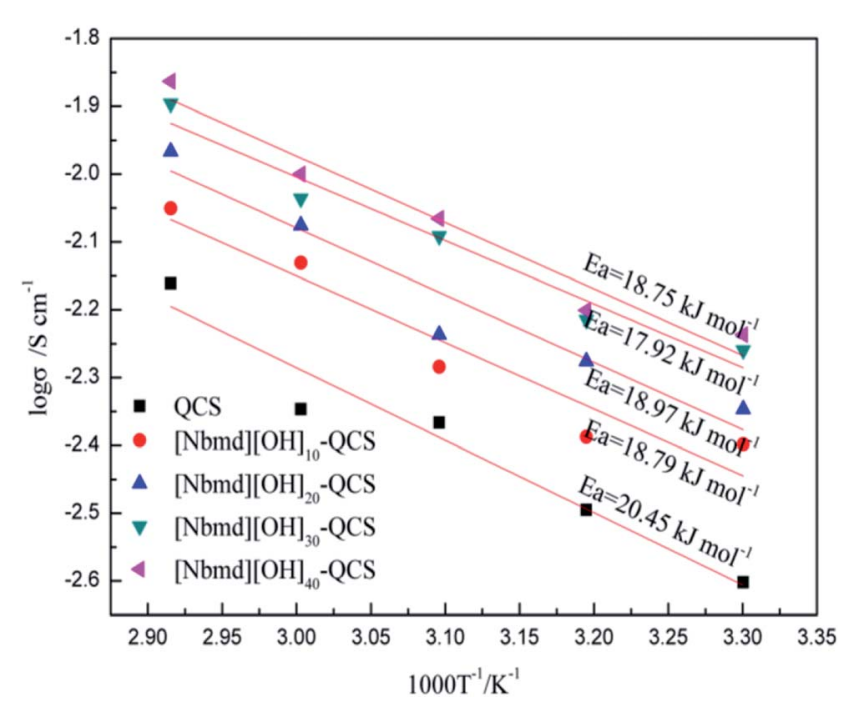

Fig. 10 Arrhenius plots for the QCS and $[\mathrm{Nbmd}][\mathrm{OH}]_{x}-\mathrm{QCS}$ membranes $(x=10,20,30,40)$. $E_{\mathrm{a}}$ : activation energy of the $\mathrm{OH}^{-}$ transportation. 
Table 4 Swelling kinetic parameters and water uptake of QCS and [Nbmd][OH] $]_{x}-$ QCS membranes $(x=10,20,30,40)$

\begin{tabular}{|c|c|c|c|c|c|c|}
\hline Samples & $W_{\mathrm{s}}^{a}$ & $W_{\infty}^{b}$ & $K_{\mathrm{s}}^{c}$ & $K_{\mathrm{s}} W_{\infty}^{2 c}$ & $R^{2}$ & Water uptake/\% \\
\hline$[\mathrm{Nbmd}][\mathrm{OH}]_{10}-\mathrm{QCS}$ & 110.00 & 119.05 & $3.53 \times 10^{-3}$ & 50.00 & 0.9953 & 132.12 \\
\hline$[\mathrm{Nbmd}][\mathrm{OH}]_{20}-\mathrm{QCS}$ & 143.00 & 153.84 & $4.02 \times 10^{-3}$ & 95.24 & 0.9934 & 223.55 \\
\hline$[\mathrm{Nbmd}][\mathrm{OH}]_{40}-\mathrm{QCS}$ & 175.00 & 183.82 & $4.88 \times 10^{-3}$ & 161.29 & 0.9976 & 336.50 \\
\hline QCS & 250.00 & 250.00 & $1.07 \times 10^{-2}$ & 666.67 & 0.9999 & 462.33 \\
\hline
\end{tabular}

${ }^{a}$ Experimental equilibrium swelling ratio (g water/g membrane). ${ }^{b}$ Theoretical equilibrium swelling ratio (g water/g membrane). ${ }^{c}(\mathrm{~g}$ water/g membrane)/min.

Table 5 IEC values and $\mathrm{OH}^{-}$conductivities of the membranes in this work and in the literature

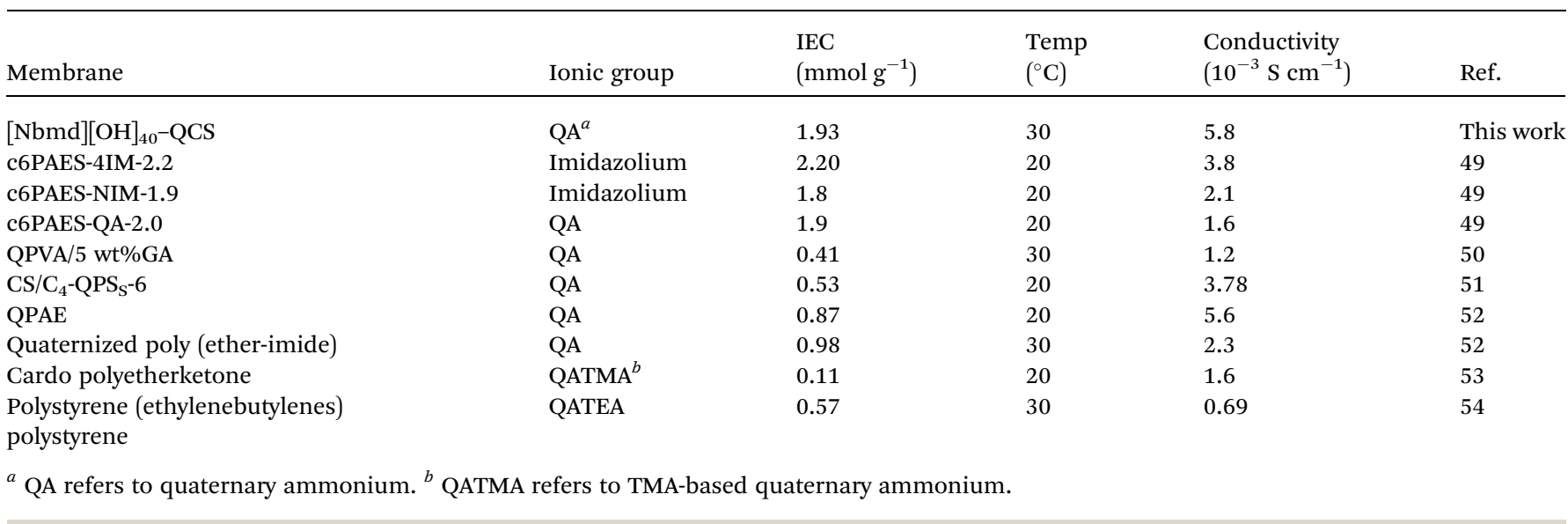

temperature. In this work, the $[\mathrm{Nbmd}][\mathrm{OH}]_{30}-\mathrm{QCS}$ membrane and the $[\mathrm{Nbmd}][\mathrm{OH}]_{40}-\mathrm{QCS}$ membrane have the largest swelling rate constant and initial swelling rate, indicating that these two membranes are the most suitable for moisture absorption. It can also be seen in Fig. 7 and 8 that even though the QCS membrane has the largest swelling ratio and swelling rate constant, its excessive swelling ratio leads to poor mechanical properties that make it impractical for application in fuel cells.

\subsection{Ionic conductivities of $[\mathrm{Nbmd}][\mathrm{OH}]_{x}$-QCS membranes}

The $\mathrm{OH}^{-}$conductivity of the membrane is of particular importance and plays a significant role in fuel cell performance. The $\mathrm{OH}^{-}$conductivity of QCS and $[\mathrm{Nbmd}][\mathrm{OH}]_{x}-\mathrm{QCS}$ membranes $(x=10,20,30,40)$, determined by means of an AC impedance method at different temperatures, is shown in Fig. 9. The following results were found. (1) The $\mathrm{OH}^{-}$conductivities of all the membranes range from $10^{-3}$ to $10^{-2} \mathrm{~S} \mathrm{~cm}^{-1}$, with the highest being $1.37 \mathrm{~S} \mathrm{~cm}^{-2}$ ([Nbmd $\left.][\mathrm{OH}]_{40}-\mathrm{QCS}\right)$. (2) Under the same temperature conditions, the $\mathrm{OH}^{-}$conductivity increases with increasing $[\mathrm{Nbmd}][\mathrm{OH}]$ content, which is because the higher [Nbmd] $[\mathrm{OH}]$ content means more positively charged groups providing $\mathrm{OH}^{-}$active sites. (3) At the same [Nbmd] $[\mathrm{OH}]$ content, all membranes show the same trend of positive correlation between the $\mathrm{OH}^{-}$conductivity and temperature. This correlation occurs because with increasing temperature, the structure of the membranes becomes relatively loose, resulting in widened run-through anion transport channels for $\mathrm{OH}^{-}$migration. ${ }^{47,48}$ Hence, the transport of $\mathrm{OH}^{-}$ anions in membranes is easier at high temperature.

Table 5 lists several IEC values and $\mathrm{OH}^{-}$conductivities of anion exchange membranes reported in the literature, which are based on quaternary ammonium groups and imidazolium groups as cationic active sites. As seen in Table 5, the [Nbmd] $[\mathrm{OH}]_{40}-\mathrm{QCS}$ membrane prepared in this work shows better

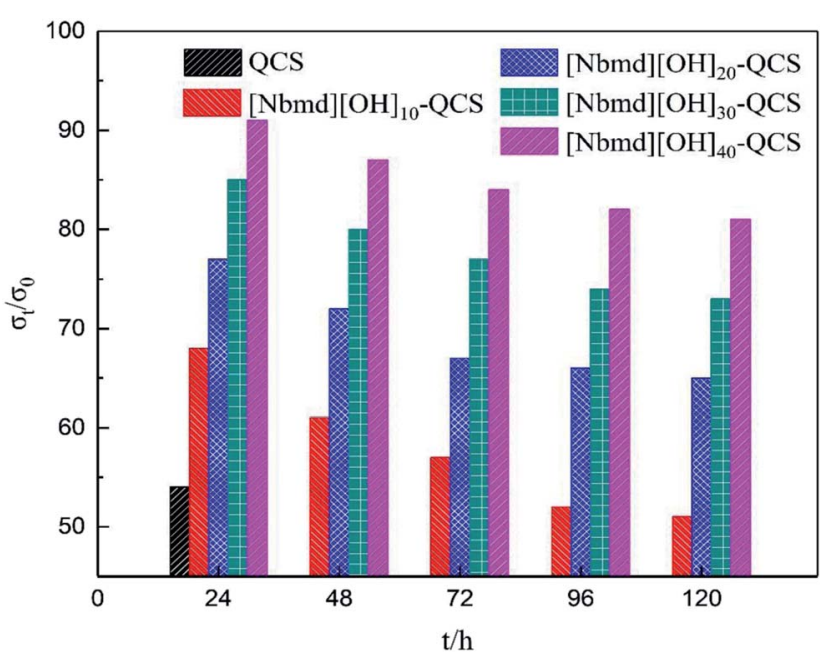

Fig. $11 \sigma_{t} / \sigma_{0}$ values of QCS and [Nbmd] $[\mathrm{OH}]_{x}-\mathrm{QCS}$ membranes $(x=$ $10,20,30,40)$ as a function of time after immersion in $\mathrm{N}_{2}$-saturated $3 \mathrm{M} \mathrm{KOH}$ aqueous solution at $70{ }^{\circ} \mathrm{C}$. 
conductivity than those in the literature. It should be noted that IEC is related to the amount of available exchangeable groups, which are actually carrier sites for $\mathrm{OH}^{-}$. The higher IEC value is the main factor causing $[\mathrm{Nbmd}][\mathrm{OH}]_{40}-\mathrm{QCS}$ membrane to have a higher conductivity than the membranes in the literature.

Fig. 10 shows the relation between $\ln \sigma$ and $1000 / T^{-1}$. Assuming that the $\mathrm{OH}^{-}$conductivity follows the Arrhenius behavior, the ion transport activation energy $E_{\mathrm{a}}$ of the composite membranes can be obtained according to the Arrhenius equation:

$$
E_{\mathrm{a}}=-b \times R
$$

where $b$ is the slope of the regression line of $\ln \sigma\left(\mathrm{S} \mathrm{cm}^{-1}\right) v s$. $1000 / T^{-1}\left(\mathrm{~K}^{-1}\right)$ plots, and $R$ is the gas constant $\left(8.314472 \mathrm{~J} \mathrm{~K}^{-1}\right.$ $\left.\mathrm{mol}^{-1}\right)$. The results are presented in Fig. 12 .

As seen in Fig. 10, the $E_{\mathrm{a}}$ values of the pure QCS and [Nbmd] $[\mathrm{OH}]_{x}-\mathrm{QCS}$ membranes $(x=10,20,30,40)$ increase with increasing [Nbmd] $[\mathrm{OH}]$ content. It is possible that, on one hand, the increasing content of $[\mathrm{Nbmd}][\mathrm{OH}]$ leads to an increased number of cationic active sites in the composite membrane, which could attract more $\mathrm{OH}^{-}$. On the other hand, the increased number of hydrophobic long carbon chains increases the degree of hydrophilic-hydrophobic phase separation, ${ }^{54-56}$ which provides convenient conditions for $\mathrm{OH}^{-}$ migration, reducing the $E_{\text {a }}$ values. In addition, the increased water uptake (Table 4) provides a better water environment for the $\mathrm{OH}^{-}$migration, which also contributes to the reduction in the $E_{\mathrm{a}}$ values. However, as the content of [Nbmd] $[\mathrm{OH}]$ continues to increase, the $E_{\mathrm{a}}$ value tends to rise, which may be related to the fact that in a composite membrane with a high [Nbmd] $[\mathrm{OH}]$ content, the long carbon chains of $[\mathrm{Nbmd}][\mathrm{OH}]$ are more easily intertwined with each other, which would impede the migration of $\mathrm{OH}^{-}$and thus increase the $E_{\text {a }}$ value.

\subsection{Methanol permeability}

In general, increases in the swelling ratio lead to greater methanol permeability because the relative relaxation of the

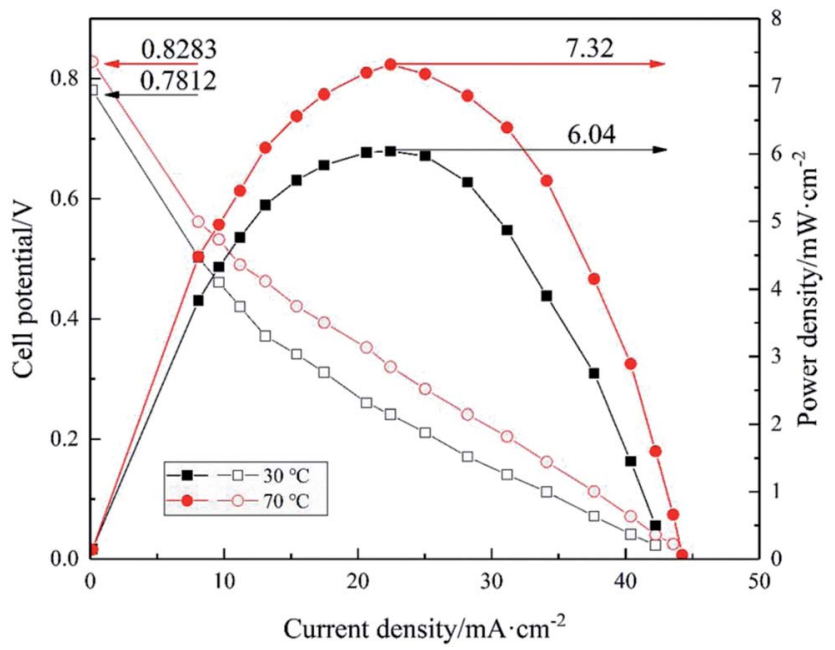

Fig. 12 Polarization and power density curves of [ $\mathrm{Nbmd}][\mathrm{OH}]_{40}-\mathrm{QCS}$ membrane at $30{ }^{\circ} \mathrm{C}$ and $70{ }^{\circ} \mathrm{C}$. membrane structure is conducive to the permeation of methanol molecules. However, in this work, as revealed in Table 6, with increasing $[\mathrm{Nbmd}][\mathrm{OH}]$ content, the composite membrane shows a trend of an increase followed by a decrease in methanol permeability. The increase occurs because when the [Nbmd] $[\mathrm{OH}]$ content is increased to $20 \%$, the composite membrane structure becomes more relaxed and is easier for methanol to pass through. However, if the $[\mathrm{Nbmd}][\mathrm{OH}]$ content is increased to $40 \%$, the methanol permeation is reduced to $2.21 \times 10^{3} \mathrm{~S} \mathrm{~s}$ $\mathrm{cm}^{-3}$, which is less than that of Nafion ${ }^{\circledR} 115$. This decrease may occur because, on one hand, a smaller proportion of QCS matrix leads to a limited swelling ratio; on the other hand, the increase in the number of hydrophobic alkane tail chains causes excessive extrusion into the hydrophilic region, resulting in narrow channels for methanol molecules to pass through.

Since the anion exchange membrane in DMFCs can be treated as a separator of $\mathrm{OH}^{-}$and methanol, in order to evaluate the efficiency of separating two components $\left(\mathrm{OH}^{-}\right.$and methanol) by the composite membrane, selectivity ${ }^{57}$ is investigated as an index. If Fick's law and the Nernst-Plank equation are applied to describe the $\mathrm{OH}^{-}$flux and methanol flux, respectively, then the $\mathrm{OH}^{-} /$methanol selectivity parameter (SP) can be expressed in the form $\mathrm{SP}=\sigma / P$, i.e., the ratio of $\mathrm{OH}^{-}$conductivity $(\sigma)$ to methanol permeability $(P)$. As can be seen in Table 6 , all composite membranes show higher selectivity than the pure QCS membrane $(\mathrm{SP}=1.9)$. The selectivity increases with increasing $[\mathrm{Nbmd}][\mathrm{OH}]$ content, and the highest value of $6.2 \times$ $10^{3} \mathrm{~S} \quad \mathrm{~s} \mathrm{~cm}^{-3}$ was obtained for the $[\mathrm{Nbmd}][\mathrm{OH}]_{40}-\mathrm{QCS}$ membrane. The improved selectivity should be attributed to the dual function of the synthesized $[\mathrm{Nbmd}][\mathrm{OH}]$, where the hydrophilic quaternized ammonium groups facilitate anion conduction, and the hydrophobic alkane tail chains resist methanol crossover. The improved selectivity with increasing [Nbmd] $[\mathrm{OH}]$ content clearly implied a promising application potential of the composite membranes for DMFC. However, both the selectivity and the methanol permeability of all the composite membranes are lower than those of Nafion®115. Therefore, further improvements of the AEMs are needed.

\subsection{Alkaline stability of QCS/[Nbmd] $\mathrm{OH}$ membranes}

The alkaline stability of AEMs is the key factor affecting the lifetime of fuel cells. It is highly desirable to develop an anion exchange membrane with both high $\mathrm{OH}^{-}$conductivity and excellent alkaline stability.

As Fig. 11 shows, with the extension of immersion time, the conductivities of all samples exhibit decreasing tendencies of different degrees. The conductivity of the QCS membrane decreased by $50 \%$ after $24 \mathrm{~h}$ of immersion, showing poor alkaline stability due to the degradation of quaternary ammonium groups by $\mathrm{OH}^{-}$attack (Hofmann elimination) ${ }^{58}$ and direct nucleophilic substitution. ${ }^{59,60}$ With increasing $[\mathrm{Nbmd}][\mathrm{OH}]$ content, the alkaline stability of the composite membranes is improved. The $[\mathrm{Nbmd}][\mathrm{OH}]_{40}$-QCS membrane exhibits the best alkaline stability, which is approximately $81 \%$ of the initial conductivity after immersion in $3 \mathrm{M} \mathrm{KOH}$ solution for $120 \mathrm{~h}$ at $70{ }^{\circ} \mathrm{C}$. This high stability is because the decrease in QCS content 
Table 6 Properties of the $[\mathrm{Nbmd}][\mathrm{OH}]_{x}-\mathrm{QCS}$ membranes $(x=10,20,30,40)$

\begin{tabular}{|c|c|c|c|c|c|c|}
\hline Membrane & Thickness $(\mu \mathrm{m})$ & \multicolumn{2}{|c|}{ IEC $\left(\mathrm{mmol} \mathrm{g}^{-1}\right)$} & $\begin{array}{l}\mathrm{OH}^{-} \text {conductivity } \\
\text { at } 70^{\circ} \mathrm{C}\left(10^{-2} \mathrm{~S} \mathrm{~cm}^{-1}\right)\end{array}$ & $\begin{array}{l}\text { Methanol permeation } \\
\left(10^{-6} \mathrm{~cm}^{-2} \mathrm{~s}^{-1}\right)\end{array}$ & $\begin{array}{l}\mathrm{SP}^{a} \\
\left(10^{3} \mathrm{~S} \mathrm{~s} \mathrm{~cm}^{-3}\right)\end{array}$ \\
\hline$[\mathrm{Nbmd}][\mathrm{OH}]_{10}-\mathrm{QCS}$ & $236 \pm 8$ & 1.56 & 1.38 & 0.89 & 3.97 & 2.2 \\
\hline$[\mathrm{Nbmd}][\mathrm{OH}]_{20}-\mathrm{QCS}$ & $223 \pm 5$ & 1.75 & 1.54 & 1.08 & 3.43 & 3.1 \\
\hline$[\mathrm{Nbmd}][\mathrm{OH}]_{30}-\mathrm{QCS}$ & $232 \pm 6$ & 1.95 & 1.71 & 1.27 & 2.87 & 4.4 \\
\hline
\end{tabular}

${ }^{a} \mathrm{SP}$ is the selectivity parameter (SP) of conductivity at $70{ }^{\circ} \mathrm{C}$ and methanol permeation at room temperature measured in this work.

leads to a lower number of quaternary ammonium groups grafted onto the QCS backbone and exposed directly to alkaline environment. However, the ionic liquid ([Nbmd] [OH] ) prepared in this experiment contains a morpholine ring, a group with high steric hindrance, which could protect the quaternary ammonium groups against $\mathrm{OH}^{-}$attack ${ }^{\mathbf{6 1 , 6 2}}$ and thereby promote an acceptable alkaline stability.

\subsection{Single-cell performance}

Fig. 12 shows the polarization and power density curves of $[\mathrm{Nbmd}][\mathrm{OH}]_{40}-\mathrm{QCS}$ membrane with the highest $\mathrm{OH}^{-}$conductivity at $30^{\circ} \mathrm{C}$ and $70^{\circ} \mathrm{C}$. 3.0 $\mathrm{M}$ ethanol combing 5.0 $\mathrm{M} \mathrm{KOH}$ were used in the cell performance tests.

As can be seen from Fig. 12, the cell performance is improved with the increasing operating temperature. The open circuit potentials (OCPs) of single cell at $30{ }^{\circ} \mathrm{C}$ and $70{ }^{\circ} \mathrm{C}$ are $0.7812 \mathrm{~V}$ and $0.8283 \mathrm{~V}$, respectively, and the peak power density is about $6.04 \mathrm{~mW} \mathrm{~cm}^{-2}$ at $30^{\circ} \mathrm{C}$, and it increases to about $7.32 \mathrm{~mW} \mathrm{~cm}^{-2}$ at $70{ }^{\circ} \mathrm{C}$. The improvement of the cell performance caused by the elevating operating temperature is mainly due to the following two reasons. Firstly, higher temperature accelerates the electrochemical reaction rate, depresses negative effect of pH difference between anode and cathode in anion exchange membrane fuel cell. Secondly, a raised temperature also increase the $\mathrm{OH}^{-}$conductivity of the membrane, which can be seen from the measured $\mathrm{OH}^{-}$conductivity results of the [Nbmd] $[\mathrm{OH}]_{40}-\mathrm{QCS}$ membrane in Fig. 9. However, the performance is still low at this stage, the performance of the fuel cell could be improved by further optimizing the electrode structure and lowering the resistance of the membranes. The poor chemical compatibility between the ionomer used (Nafion ${ }^{\circledR}$ ionomer) in the electrodes and the quaternary ammonium-type composite membrane is likely to be the cause of the poor performance observed. Chemical incompatibilities such as this can cause high contact resistances and poor MEA lamination. Another possible reason is the low Pt loading level of the anode and cathode $\left(0.5 \mathrm{mg} \mathrm{cm}^{-2}\right)$.

\section{Conclusions}

A new gemini basic morpholine ionic liquid ([Nbmd $][\mathrm{OH}])$ was synthesized via a two-step procedure and applied to the preparation of $[\mathrm{Nbmd}][\mathrm{OH}]_{x}-\mathrm{QCS}$ membranes due to its good thermal stability, strong polarity and alkalinity. The characterization results show that, with increasing $[\mathrm{Nbmd}][\mathrm{OH}]$ content, increasing trends can be observed in water uptake, swelling ratio and thermal stability, while a slight decrease can be found in TS values. However, the methanol permeation of the composite membrane shows a trend of first increasing and then decreasing, with the lowest methanol permeation being $2.21 \times$ $10^{3} \mathrm{~S} \mathrm{~s} \mathrm{~cm}^{-3}$, which is less than that of Nafion®115. The [Nbmd] $[\mathrm{OH}]_{40}-\mathrm{QCS}$ membrane also possesses the highest $\mathrm{OH}^{-}$ conductivity of all the prepared membranes, reaching $1.37 \mathrm{~S}$ $\mathrm{cm}^{-2}$ at $70^{\circ} \mathrm{C}$. Furthermore, the $[\mathrm{Nbmd}][\mathrm{OH}]_{40}-\mathrm{QCS}$ membrane exhibits the best alkaline stability, which is approximately $81 \%$ of the initial conductivity after immersion in $3 \mathrm{M} \mathrm{KOH}$ solution for $120 \mathrm{~h}$ at $70^{\circ} \mathrm{C}$, indicating a promising application potential in direct methanol fuel cells.

\section{Conflicts of interest}

There are no conflicts to declare.

\section{Acknowledgements}

We gratefully acknowledge the Scientific Research Fund of Liaoning Provincial Education Department (L2013153), the Fundamental Research Funds for the Doctoral of Liaoning Provincial Natural Science Foundation (20141126), the Science and Technology Development Fund Project of Fushun City (20141115), and the Scientific Research Cultivation Fund of LSHU of China for their financial support.

\section{References}

1 B. C. H. Steele\&Amp and A. Heinzel, Nature, 2001, 345-352.

2 M. Z. Jacobson, W. G. Colella and D. M. Golden, Science, 2005, 308, 1901.

3 Y. J. Wang, J. Qiao, R. Baker and J. Zhang, Chem. Soc. Rev., 2013, 42, 5768-5787.

4 O. Z. Sharaf and M. F. Orhan, Renewable Sustainable Energy Rev., 2014, 32, 810-853.

5 L. A. Neves, P. J. Sebastião, I. M. Coelhoso and J. G. Crespo, J. Phys. Chem. B, 2011, 115, 8713-8723.

6 L. Zhu, J. Pan, Y. Wang, J. Han, L. Zhuang and M. A. Hickner, Macromolecules, 2016, 49, 815-824. 
7 J. Pan, J. Han, L. Zhu and M. A. Hickner, Chem. Mater., 2017, 29, 5321-5330.

8 L. Zhu, J. Pan, C. M. Christensen, B. Lin and M. A. Hickner, Macromolecules, 2016, 49.

9 H. Long and B. Pivovar, J. Phys. Chem. C, 2014, 118, 98809888.

10 S. Chempath, J. M. Boncella, L. R. Pratt, N. Henson and B. S. Pivovar, J. Phys. Chem. C, 2010, 114, 11977-11983.

11 J. R. Varcoe and R. C. T. Slade, Fuel Cells, 2005, 5, 187-200.

12 J. Yang, Q. Che, L. Zhou, R. He and R. F. Savinell, Electrochim. Acta, 2011, 56, 5940-5946.

13 C. Wang, B. Lin, G. Qiao, L. Wang, L. Zhu and F. Chu, Mater. Lett., 2016, 173, 219-222.

14 H. Zhu, R. Li, F. Wang, N. Chen, Z. Li and Z. Wang, J. Mater. Sci., 2017, 52, 11109-11119.

15 X. Zhu, B. Wang and H. Wang, Polym. Bull., 2010, 65, 719730.

16 S. Yi, F. Zhang, L. Wei, H. Chi, H. Zhang and P. Mu, J. Membr. Sci., 2011, 366, 349-355.

17 R. A. Patil, M. Talebi, L. M. Sidisky and D. W. Armstrong, Chromatographia, 2017, 1-12.

18 G. Ding, W. Zhang, Z. Zhang, D. Guo, G. Tang and Y. Li, Anal. Bioanal. Chem., 2017, 1-12.

19 A. S. Khan, Z. Man, A. Arvina, M. A. Bustam, A. Nasrullah and Z. Uiiah, J. Mol. Liq., 2017, 227, 98-105.

20 L. L. Wang, Y. Zhang, F. Zhang and R. Feng, Energy Sources, Part A, 2016, 38, 2770-2776.

21 Y. Wan, B. Peppley, K. A. M. Creber, V. T. Bui and E. Halliop, J. Power Sources, 2008, 185, 183-187.

22 J. L. Wang and R. H. He, Solid State Ionics, 2015, 278, 49-57.

23 R. He, Q. Li, A. Bach, J. O. Jensen and N. J. Bjerrum, J. Membr. Sci., 2006, 277, 38-45.

24 C. Yang, S. Wang, W. Ma, L. Jiang and G. Sun, J. Mater. Chem. A, 2015, 3, 8559-8565.

25 C. Klaysom, R. Marschall, S. H. Moon, B. P. Ladewig and G. Q. M. Lu, J. Mater. Chem., 2011, 21, 7401-7409.

26 M. R. Hibbs, M. A. Hickner, T. M. Alam, S. K. Mcintyre and C. H. Fujimoto, Chem. Mater., 2008, 20, 2566-2573.

27 J. Parrondo, M. S. J. Jung, Z. Wang, C. G. Arges and V. Ramani, J. Electrochem. Soc., 2015, 162, F1236-F1242.

28 Y. Wu, C. Wu, T. Xu, F. Yu and Y. Fu, J. Membr. Sci., 2008, 321, 299-308.

29 D. Z. Liu, X. X. Hou, X. L. Zhu, R. Wang, J. Jing and Y. Cui, Acta Phys.-Chim. Sin., 2013, 29, 2573-2578.

30 Y. Wan, B. Peppley, K. A. M. Creber and V. T. Bui, J. Power Sources, 2010, 195, 3785-3793.

31 Y. Li, E. Wang, S. Wang, Y. Lu, C. Hu and N. Hu, J. Mol. Struct., 2002, 607, 133-141.

32 A. Them, J. Nanotechno., 2017, 2017, 1-10.

33 Y. F. Wang, H. T. Wan, J. L. Wang, L. L. Wang and R. J. Feng, J. Electrochem. Soc., 2017, 164, F1051-F1062.

34 H. L. Kang, D. H. Cho, Y. M. Kim, J. M. Sun and J. G. Seong, Energy Environ. Sci., 2016, 10, 275-285.

35 C. Yang, S. Wang, W. Ma, S. Zhao and Z. Xu, J. Mater. Chem. A, 2016, 4, 3886-3892.
36 R. Narducci, J. Chailan, A. Fahs, L. Pasquini and M. L. D. Vona, J. Polym. Sci., Part B: Polym. Phys., 2016, 54, 1180-1187.

37 C. X. Lin, Y. Z. Zhuo, A. N. Lai, Q. G. Zhang and A. M. Zhu, J. Membr. Sci., 2016, 513, 206-216.

38 X. Lin, X. Liang, S. D. Poynton, J. R. Varcoe, L. O. Ai and J. Ran, J. Membr. Sci., 2013, 443, 193-200.

39 X. Li, G. Nie, J. Tao, W. Wu, L. Wang and S. Liao, ACS Appl. Mater. Interfaces, 2014, 6, 7585.

40 J. Ran, L. Wu and T. Xu, Polym. Chem., 2013, 4, 4612-4620.

41 P. Y. Xu, K. Zhou, G. L. Han, Q. G. Zhang, A. M. Zhu and Q. L. Liu, ACS Appl. Mater. Interfaces, 2014, 6, 6776.

42 L. L. Wang, J. L. Wang and R. J. Feng, J. Fuel Chem. Technol., 2015, 43, 59-64.

43 B. Kim, K. L. Flamme and N. A. Peppas, J. Appl. Polym. Sci., 2010, 89, 1606-1613.

44 Q. Duan, S. Ge and C. Y. Wang, J. Power Sources, 2013, 243, 773-778.

45 D. J. Enscor, H. B. Hopfenber, V. T. Stannett and A. R. Berens, Polymer, 1977, 18, 1105-1110.

46 E. Díezpeña, I. Quijadagarrido and J. M. Barralesrienda, Macromolecules, 2003, 36, 2475-2483.

47 Y. Xiong, Q. L. Liu, Q. G. Zhang and A. M. Zhu, J. Power Sources, 2008, 183, 447-453.

48 E. A. Weiber and P. Jannasch, J. Membr. Sci., 2016, 520, 425433.

49 C. C. Yang, S. S. Chiu and S. C. Kuo, J. Power Sources, 2012, 199, 37-45.

50 H. Zhang, B. Shi, R. Ding, H. Chen, J. Wang and J. Liu, Ind. Eng. Chem. Res., 2016, 55, 9064-9076.

51 X. Li, Q. Liu, Y. Yu and Y. Meng, J. Mater. Chem. A, 2013, 1, 4324-4335.

52 Q. H. Zeng, Q. L. Liu and I. Broadwell, J. Membr. Sci., 2010, 349, 237-243.

53 J. Wang, S. Li and S. Zhang, Macromolecules, 2010, 43, 38903896.

54 X. Wu, W. Chen, X. Yan, G. He, J. Wang and Y. Zhang, J. Mater. Chem. A, 2014, 2, 12222-12231.

55 X. Yan, S. Gu, G. He, X. Wu and J. Benziger, J. Power Sources, 2014, 250, 90-97.

56 J. J. Han, Q. Liu, X. Q. Li, J. Pan, L. Wei, Y. Wu, H. Q. Peng, Y. Wang, G. W. Li, C. Chen, L. Xiao, J. T. Lu and L. Zhuang, ACS Appl. Mater. Interfaces, 2015, 7, 2809-2816.

57 B. Libby, W. H. Smyrl and E. L. Cussler, AIChE J., 2003, 49, 991-1001.

58 Y. S. Ye and Y. A. Elabd, Macromolecules, 2011, 44, 84948503.

59 C. S. Macomber, J. M. Boncella, B. S. Pivovar and J. A. Rau, J. Therm. Anal. Calorim., 2008, 93, 225-229.

60 S. Chempath, B. R. Einsla, L. R. Pratt, C. S. Macomber, J. M. Boncella, J. A. Rau and B. S. Pivovar, J. Phys. Chem. C, 2008, 112, 3179-3182.

61 S. Gu, R. Cai, T. Luo, Z. W. Chen, M. W. Sun, Y. Liu, G. H. He and Y. S. Yan, Angew. Chem., Int. Ed., 2009, 48, 6499.

62 K. J. Noonan, K. M. Hugar, H. A. Kostalik, E. B. Lobkovsky, H. D. Abruña and G. W. Coates, J. Am. Chem. Soc., 2012, 134, 18161-18164. 